\begin{tabular}{c|l|l|l}
$\begin{array}{c}\text { Case Reports in } \\
\text { Oncology }\end{array}$ & $\begin{array}{l}\text { Case Rep Oncol 2011;4:198-203 } \\
\text { DOl: 10.1159/000327689 }\end{array}$ & $\begin{array}{l}\text { Published online: } \\
\text { April 6, 2011 }\end{array}$ & $\begin{array}{l}\text { O 2011 S. Karger AG, Basel } \\
\text { ISSN 1662-6575 } \\
\text { www.karger.com/cro }\end{array}$ \\
\hline
\end{tabular}

\title{
Multiple Myeloma Emerging after Prolonged Gefitinib Treatment for Non-Small Cell Lung Carcinoma
}

\author{
Sian Yik Lim ${ }^{a}$ Sachiko Ando ${ }^{b}$ Kaoru Nishiyama \\ Simi Padivala \\ Departments of a General Internal Medicine, ${ }^{\mathrm{b}} \mathrm{Hematology}$, and ${ }^{\mathrm{c} P u l m o n o l o g y,}$ \\ Teine Keijinkai Hospital, Sapporo, Japan
}

\section{Key Words}

Multiple myeloma $\cdot$ Gefitinib · Non-small cell lung carcinoma

\begin{abstract}
The coexistence of lung cancer and multiple myeloma (MM) is rare. A search of the English literature revealed only 5 case reports to date. We describe a case of MM that presented in a 78-year-old lung cancer patient after 20 months of treatment with gefitinib, an epidermal growth factor receptor tyrosine kinase inhibitor. We also review previously reported cases of concurrent development of lung cancer and MM.
\end{abstract}

\section{Introduction}

Multiple myeloma (MM) is a rare post-germinal center B-cell malignancy. The coexistence of MM and lung cancer is uncommon. A search of the English literature for synchronous cases of lung cancer and MM revealed only 5 cases (table 1) [1-5].

Gefitinib is an epidermal growth factor receptor tyrosine kinase inhibitor (EGFR-TKI) used to treat non-small cell lung carcinoma [6]. EGFR is expressed in a wide range of solid tumors, as well as in malignant myeloma cells [7]. Binding of the ligand to EGFR activates tyrosine kinase activity in the intracellular domain, leading to the initiation of signal transduction cascades involved in malignant cell proliferation and survival. Small molecule tyrosine kinase inhibitors (gefitinib, erlotinib) and an EGFR-specific antibody (cetuximab) were developed as first generation anti-EGFR therapies [6].

We describe a case of MM that presented in a lung cancer patient who was treated with gefitinib for 20 months. To our knowledge, this is the first such case reported in the 
literature. Previous cases of concurrent development of lung cancer and MM are also reviewed.

\section{Case Report}

A 78-year-old male presented to our pulmonology department for a workup of a right lung nodule (fig. 1) and right supraclavicular lymph node swelling (fig. 2). The patient was diagnosed with stage IV lung adenocarcinoma (EGFR mutation-positive) based on supraclavicular lymph node biopsy. Gefitinib therapy was initiated at $250 \mathrm{mg} /$ day for 3 months. The dose of gefitinib had to be reduced to $250 \mathrm{mg}$ every other day due to hepatotoxicity, but it was continued for 17 months. Gefitinib treatment successfully controlled the progression of the tumor and the patient maintained excellent functional status throughout the course of treatment.

Twenty months after initiation of the gefitinib therapy, rapid progression of the lung tumor was noted with a mild decrease in white blood cells, red blood cells, and platelet count. It was initially supposed that this was due to the progression of adenocarcinoma of the lung and the patient was admitted for chemotherapy. He received carboplatin, paclitaxel, bevacizumab, and supportive therapy with granulocyte colony stimulating factor. After the first course of chemotherapy, the patient was restaged and the tumor showed a partial response. The patient continued to have pancytopenia after chemotherapy, which required frequent blood transfusions and supportive therapy. Therefore, he was referred to a hematologist for further evaluation.

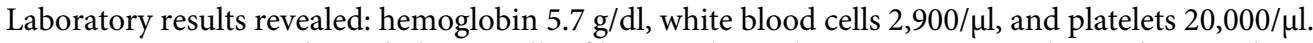
Bone marrow aspiration showed plasma cell infiltration (84.8\%). Serum immunoelectrophoresis showed monoclonal gammopathy with IgG $\lambda$ protein and Bence-Jones $\lambda$ protein, and urinalysis was also positive for Bence-Jones $\lambda$ protein. Serum immunoelectrophoresis also revealed a decrease in albumin and beta globulin (41.8 and 6.4\%, respectively) and an increase in gamma globulin (42.3\%). Flow cytometric immunophenotyping indicated that plasma cells, as gated by bright expression of CD 38 and CD 138, were negative for CD 19, CD 56, CD 49e, and MPC 1. Karyotyping was abnormal and showed the following: 53, XY, $+\operatorname{add}(3)(q 21),+5,+6,+7,+9,-13,+18,+21$.

Additional laboratory work revealed: $\beta 2$-microglobulin $6.0 \mathrm{mg} / \mathrm{l}$, albumin $2.4 \mathrm{mg} / \mathrm{dl}, \mathrm{Ca} 11.1 \mathrm{mg} / \mathrm{dl}$, Cr 1.34, IgG $3.6 \mathrm{~g} / \mathrm{dl}$, IgA $0.018 \mathrm{~g} / \mathrm{dl}$, and IgM $0.010 \mathrm{~g} / \mathrm{dl}$. No bone lesions were detected on skeletal survey. Diagnostic thoracentesis demonstrated an infiltration of plasma cells in the pleural fluid, which was confirmed by flow cytometry analysis. Thus, the diagnosis of MM (Durie Salmon IIIA, ISS III, SWOG III) was made in coexistence with stage IV lung adenocarcinoma. Conservative treatment with moderate doses of steroids and bortezomib was instituted. Despite partial remission of disease, the patient's clinical course deteriorated and he died 2 weeks after admission to the hematology service.

\section{Review of the Literature}

Table 1 shows cases of synchronous lung cancer and MM reported in the English literature. All patients were male with a median age of 63 years (range 51-78). Four cases were diagnosed simultaneously during diagnostic workup for the initially diagnosed tumor. Marinopoulos et al. [4] reported a case of MM developing 6 months after initiation of chemotherapy for lung cancer. The histology of lung cancer was variable, and included 2 cases of adenocarcinoma, 2 cases of squamous cell carcinoma, and 1 case of small cell lung carcinoma. The myeloma isotype was IgG in all patients.

\section{Discussion}

It is difficult to determine whether synchronous MM and lung cancer occurred by chance, or if there is an association between the two tumors. Multiple primary cancers in 
the same individual could reflect the influence of antecedent cancer therapy, as well as shared etiologic factors such as environmental exposure, genetic susceptibility, lifestyle choices, and the combinations of effects [8].

Common environmental factors for lung cancer and $\mathrm{MM}$ include ionizing radiation and pesticides [9-11]. Several case reports of familial MM observed BRCA-1, BRCA-2, and p16 mutations in those families, suggesting that there may be a genetic predisposition [12]. When the development of lung cancer precedes MM or vice versa, it is possible that the antecedent cancer of the first tumor contributed to the development of the second tumor. While Marinopoulos et al. [4] reported a case of MM developing after the initiation of chemotherapy for lung cancer, a thorough search of the literature did not find any cases of MM in association with gefitinib.

The etiology of the synchronous cancer occurrence in our patient is unclear, however, he had a strong family history of cancer (his father had pancreatic cancer and his mother had esophageal cancer). Being a nonsmoker and office worker by profession, no clear environmental exposure could be identified. Moreover, he did not have a history of chronic inflammatory disease.

Mahtouk et al. [7] reported that EGFR is expressed on malignant plasma cells of MM and on cells of the MM microenvironment. It has been shown that inhibition of EGFRligand signaling potentiates dexamethasone-induced MM cell apoptosis [13]. Currently, the safety and efficacy of cetuximab, an EGFR-specific antibody, is being evaluated for relapsed MM in a phase II study (ClinicalTrials.gov identifier: NCT00368121).

Stabilization of relapsed MM with cetuximab treatment has also been reported [14]. Development of MM in the setting of prolonged EGFR inhibition as in our case is interesting in view of recent reports suggesting a role for EGFR inhibitors in refractory MM therapy. Although an EGFR mutation was confirmed via metastatic lymph node biopsy in our patient, the status of EGFR expression or if EGFR mutation was present in myeloma cells is unclear. Whether or not the presence of EGFR mutation determination would be useful in defining subsets of MM that are responsive to anti-EGFR therapy, as in the case of non-small cell carcinoma, remains to be investigated.

There is no clear consensus on the treatment regimen for synchronous MM and lung cancer due to the extreme rarity of the combination. In previously reported cases, treatment was directed to the malignancy that was more advanced or the malignancy that carried a poorer prognosis. Several chemotherapeutic agents (cisplatin, docetaxel, vinorelbine, and topotecan) used in lung cancer treatment are sometimes included in MM treatment regimens as well [4]. In our patient, steroids and bortezomib were used. Bortezomib, a small molecule proteasome inhibitor, has activity both in MM and lung cancer. A phase II trial of this agent reported modest single-agent activity in patients with relapsed or refractory advanced non-small cell lung carcinoma [15].

In summary, we present a case of MM that developed in the setting of prolonged gefitinib treatment for lung cancer. Much is still unknown about the role of EGFR in MM and further studies are warranted. Currently, there are no reports associating gefitinib with the development of MM, but caution should be used in determining the long-term side effects of this relatively new drug. 


\begin{tabular}{r|l|l|l}
$\begin{array}{r}\text { Case Reports in } \\
\text { Oncology }\end{array}$ & $\begin{array}{l}\text { Case Rep Oncol 2011;4:198-203 } \\
\text { DOI: 10.1159/000327689 }\end{array}$ & $\begin{array}{l}\text { Published online: } \\
\text { April 6, 2011 }\end{array}$ & $\begin{array}{l}\text { O 2011 S. Karger AG, Basel } \\
\text { ISSN 1662-6575 } \\
\text { www.karger.com/cro }\end{array}$ \\
\hline
\end{tabular}

Table 1. Case reports of concurrent MM and lung cancer characteristics

\begin{tabular}{|c|c|c|c|c|c|c|c|c|c|c|}
\hline \multirow[t]{2}{*}{ Reference } & \multirow[t]{2}{*}{ Sex } & \multicolumn{2}{|l|}{ Age } & \multicolumn{3}{|l|}{ MM } & \multicolumn{3}{|c|}{ Lung cancer } & \multirow[t]{2}{*}{$\mathrm{F} / \mathrm{U}$} \\
\hline & & $\begin{array}{l}\mathrm{MM} \\
\mathrm{dx}\end{array}$ & $\begin{array}{l}\text { lung } \\
\text { cancer } \\
\mathrm{dx}\end{array}$ & isotype & stage & therapy & histology & stage & therapy & \\
\hline 1 & $\mathrm{M}$ & 72 & 72 & $\operatorname{IgG} \kappa$ & N/A & MP & SCC & N/A & $\mathrm{R}$ & $\begin{array}{l}\text { Death } 3 \text { month after } \mathrm{dx} \text { due to } \\
\text { sepsis }\end{array}$ \\
\hline 3 & M & 63 & 63 & $\operatorname{IgG} \kappa$ & IIIA & - & $\mathrm{ADC}$ & IV & $\mathrm{C} / \mathrm{T}$ & N/A \\
\hline 2 & $\mathrm{M}$ & 51 & 51 & $\operatorname{IgG} \kappa$ & I & - & SCLC & $\begin{array}{l}\text { Limited } \\
\text { disease }\end{array}$ & $\mathrm{C} / \mathrm{E} / \mathrm{R}$ & Death due to brain metastasis \\
\hline 4 & $\mathrm{M}$ & $67^{*}$ & 67 & $\operatorname{IgG} \kappa$ & N/A & - & $\mathrm{ADC}$ & IB & $\begin{array}{l}\mathrm{C} / \mathrm{T}(4) \\
\mathrm{C} / \mathrm{T} / \mathrm{V} / \mathrm{To} \\
(5)\end{array}$ & N/A \\
\hline 5 & $\mathrm{M}$ & 52 & 52 & $\operatorname{IgG} \lambda$ & N/A & $\mathrm{D}$ & SCC & IB & Surgery & $\mathrm{F} / \mathrm{U}$ at clinic \\
\hline Our case & M & 78 & 75 & $\operatorname{IgG} \lambda$ & IIIA & TD & $\mathrm{ADC}$ & IV & $\begin{array}{l}\text { Efitinib } \\
\text { C/T/B }\end{array}$ & $\begin{array}{l}\text { Death } 2 \text { weeks } \\
\text { after MM dx }\end{array}$ \\
\hline
\end{tabular}

$\mathrm{MM}=$ Multiple myeloma; $\mathrm{dx}=$ diagnosis; $\mathrm{MP}=$ mephalan, prednisone; $\mathrm{TD}=$ thalidomide, dexamethasone; $\mathrm{SCC}=$ squamous cell carcinoma; $\mathrm{ADC}=$ adenocarcinoma; $\mathrm{SCLC}=$ small cell lung cancer; $\mathrm{R}=$ radiotherapy $\mathrm{C}=$ carboplatin $\mathrm{T}=$ taxane; $\mathrm{E}=$ etoposide; $\mathrm{V}=$ vinorelbine; $\mathrm{To}=$ topotecan; $\mathrm{B}=$ bevacizumab; $\mathrm{N} / \mathrm{A}=$ not available; $\mathrm{F} / \mathrm{U}=$ follow-up.

Figures in parentheses represent the number of chemotherapy courses. ${ }^{*} 6$ months after initial diagnosis of lung cancer.

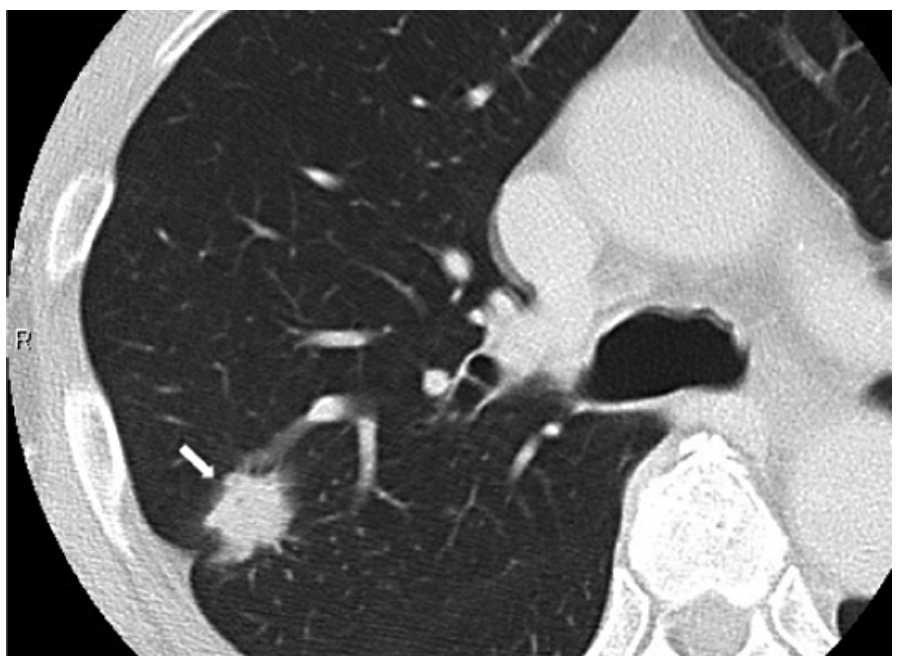

Fig. 1. Right lung nodule (arrow). 


\begin{tabular}{c|l|l|l}
$\begin{array}{c}\text { Case Reports in } \\
\text { Oncology }\end{array}$ & $\begin{array}{l}\text { Case Rep Oncol 2011;4:198-203 } \\
\text { DOl: 10.1159/000327689 }\end{array}$ & $\begin{array}{l}\text { Published online: } \\
\text { April 6, 2011 }\end{array}$ & $\begin{array}{l}\text { O 2011 S. Karger AG, Basel } \\
\text { ISSN 1662-6575 } \\
\text { www.karger.com/cro }\end{array}$ \\
\hline
\end{tabular}

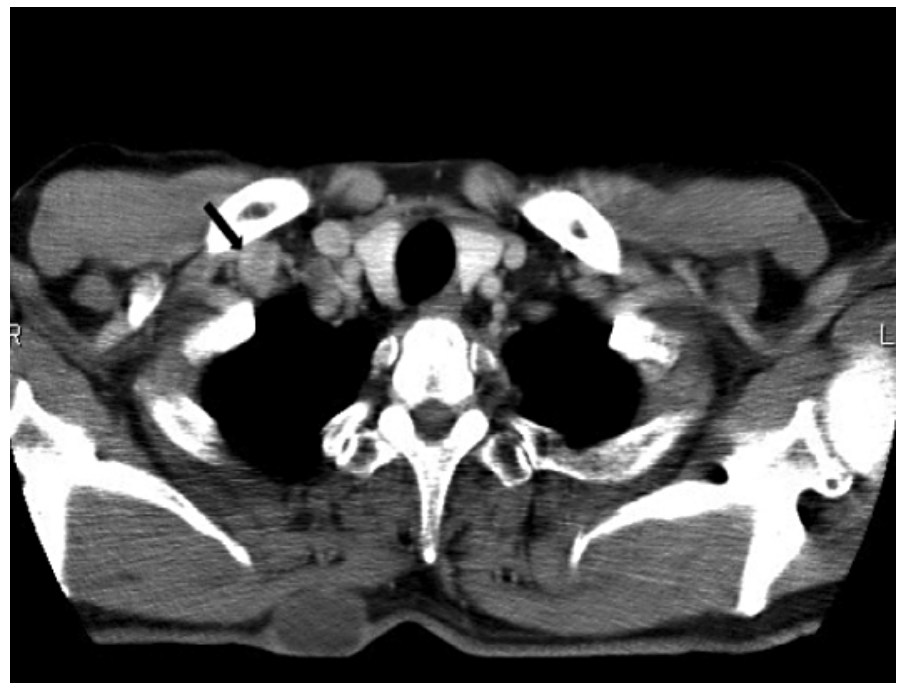

Fig. 2. Right supraclavicular lymphadenopathy (arrow). 


\section{References}

$>1$ Christou L, Tsiara L, Frangides Y, Pnevmatikos J, Briasoulis E, Galanakis E, Bourantas KL: Patients with multiple myeloma and solid tumors: six case reports. J Exp Clin Cancer Res 1998;17:239-242.

-2 Ji SH, Park JO, Lee J, Oh MJ, Lim DH, Park BB, Park KW, Lee SH, Kim K, Kim WS, Jun CW, Park YS, Im YH, Kang WK, Lee MH, Park K: Three cases of synchronous solid tumor and multiple myeloma. Cancer Res Treat 2004;36:338-340.

-3 Agarwal R, Gupta R, Bhaskar A, Sharma A, Thulkar S, Kumar L: Synchronous presentation of multiple myeloma and lung cancer. J Clin Oncol 2008;26:5814-5816.

4 Marinopoulos S, Skorda S, Karatapanis S, Rasidakis A: Multiple myeloma emerging after chemotherapy for non-small-cell lung cancer. Med Oncol 2008;25:415-418.

5 Goto T, Maeshima A, Oyamada Y, Kato R: Definitive diagnosis of multiple myeloma from rib specimens resected at thoracotomy in a patient with lung cancer. Interact Cardiovasc Thorac Surg 2010;10:1051-1053.

6 Pao W, Chmielecki J: Rational, biologically based treatment of EGFR-mutant non-small-cell lung cancer. Nat Rev Cancer 2010;10:760-774.

7 Mahtouk K, Hose D, Rème T, De Vos J, Jourdan M, Moreaux J, Fiol G, Raab M, Jourdan E, Grau V, Moos M, Goldschmidt H, Baudard M, Rossi JF, Cremer FW, Klein B: Expression of EGF-family receptors and amphiregulin in multiple myeloma. Amphiregulin is a growth factor for myeloma cells. Oncogene 2005;24:3512-3524

18 Ng AK, Travis LB: Subsequent malignant neoplasms in cancer survivors. Cancer J 2008;14:429-434.

9 Morgan GJ, Davies FE, Linet M: Myeloma aetiology and epidemiology. Biomed Pharmacother 2002;56:223234

10 Alberg AJ, Samet JM: Epidemiology of lung cancer. Chest 2003;123(1 suppl):21S-49S.

-11 Alavanja MC, Dosemeci M, Samanic C, Lubin J, Lynch CF, Knott C, Barker J, Hoppin JA, Sandler DP, Cobie J, Thomas K, Blair A: Pesticides and lung cancer risk in the agricultural health study cohort. Am J Epidemiol 2004; $160: 876-885$.

-12 Lynch HT, Ferrara K, Barlogie B, Coleman EA, Lynch JF, Weisenburger D, Sanger W, Watson P, Nipper H, Witt V, Thomé S: Familial myeloma. N Engl J Med 2008;359:152-157.

13 Mahtouk K, Jourdan M, De Vos J, Hertogh C, Fiol G, Jourdan E, Rossi JF, Klein B: An inhibitor of the EGF receptor family blocks myeloma cell growth factor activity of HB-EGF and potentiates dexamethasone or antiIL-6 antibody-induced apoptosis. Blood 2004;103:1829-1837.

14 Böll B, Eichenauer DA, Von Tresckow B, Peine D, Hallek M, Engert A, Hübel K: Activity of cetuximab as single agent in a patient with relapsed multiple myeloma. Leuk Lymphoma 2010;51:562-564.

15 Fanucchi MP, Fossella FV, Belt R, Natale R, Fidias P, Carbone DP, Govindan R, Raez LE, Robert F, Ribeiro M, Akerley W, Kelly K, Limentani SA, Crawford J, Reimers HJ, Axelrod R, Kashala O, Sheng S, Schiller JH: Randomized phase II study of bortezomib alone and bortezomib in combination with docetaxel in previously treated advanced non-small-cell lung cancer. J Clin Oncol 2006;24:5025-5033. 